\title{
Combined use of stable isotopes and fallout radionuclides as soil erosion indicators in a forested mountain site, South Korea
}

\author{
K. Meusburger ${ }^{1}$, L. Mabit ${ }^{1}$, J.-H. Park ${ }^{2}$, T. Sandor ${ }^{3}$, and C. Alewell ${ }^{1}$ \\ ${ }^{1}$ Environmental Geosciences, University of Basel, Bernoullistrasse 30, 4056 Basel, Switzerland \\ ${ }^{2}$ Department of Environmental Science \& Engineering, Ewha Womans University, Seoul 120-750, Republic of Korea \\ ${ }^{3}$ Radioanalytical Reference Laboratory, Central Agricultural Office Food and Feed Safety Directorate, Hungary
}

Correspondence to: K. Meusburger (katrin.meusburger@unibas.ch)

Received: 7 January 2013 - Published in Biogeosciences Discuss.: 12 February 2013

Revised: 13 May 2013 - Accepted: 15 June 2013 - Published: 26 August 2013

\begin{abstract}
The aim of this study is to assess and to validate the suitability of the stable nitrogen and carbon isotope signature as soil erosion indicators in a mountain forest site in South Korea. Our approach is based on the comparison of the isotope signature of "stable" landscape positions (reference sites), which are neither affected by erosion nor deposition, with eroding sites. For undisturbed soils we expect that the enrichment of $\delta^{15} \mathrm{~N}$ and $\delta^{13} \mathrm{C}$ with soil depth, due to fractionation during decomposition, goes in parallel with a decrease in nitrogen and carbon content. Soil erosion processes potentially weaken this correlation. The ${ }^{137}$ Cs method and the Revised Universal Soil Loss Equation (RUSLE) were applied for the soil erosion quantification. Erosion rates obtained with the ${ }^{137} \mathrm{Cs}$ method range from $0.9 \mathrm{tha}^{-1} \mathrm{yr}^{-1}$ to $7 \mathrm{tha}^{-1} \mathrm{yr}^{-1}$. Considering the steep slopes of up to $40^{\circ}$ and the erosive monsoon events ( $\mathrm{R}$ factor of $6600 \mathrm{MJ} \mathrm{mm} \mathrm{ha}^{-1}$ $\mathrm{h}^{-1} \mathrm{yr}^{-1}$ ), the rates are plausible and within the magnitude of the RUSLE-modeled soil erosion rates, varying from $0.02 \mathrm{tha}^{-1} \mathrm{yr}^{-1}$ to $5.1 \mathrm{tha}^{-1} \mathrm{yr}^{-1}$. The soil profiles of the reference sites showed significant $(p<0.0001)$ correlations between nitrogen and carbon content and its corresponding $\delta^{15} \mathrm{~N}$ and $\delta^{13} \mathrm{C}$ signatures. In contrast, for the eroding sites this relationship was weaker and for the carbon not significant. These results confirm the usefulness of the stable carbon isotope signature as a qualitative indicator for soil disturbance. We could show further that the $\delta^{15} \mathrm{~N}$ isotope signature can be used similarly for uncultivated sites. We thus propose that the stable $\delta^{15} \mathrm{~N}$ and $\delta^{13} \mathrm{C}$ signature of soil profiles could serve as additional indicators confirming the accurate choice of the reference site in soil erosion studies using the ${ }^{137} \mathrm{Cs}$ method.
\end{abstract}

\section{Introduction}

Landslides (Lee, 2004), deforestation (Woo et al., 1995) and forest fires (Park et al., 2012) threaten the resource soil in Korea (Kim et al., 2008). Compared to these mentioned processes, sheet (inter-rill) erosion of soils is a gradual process which passes mostly unseen especially on noncultivated sites but may be responsible for high sediment loss. The quantification of soil erosion rates with traditional approaches often requires labor-intensive long-term monitoring programs. As an alternative, fallout radionuclides (FRNs), and more particularly ${ }^{137} \mathrm{Cs}$, have been used worldwide to evaluate soil erosion rates (Zapata, 2003; Mabit et al., 2008a). To date, artificial fallout radionuclides (e.g. ${ }^{137} \mathrm{Cs}$, ${ }^{90} \mathrm{Sr},{ }^{239}+{ }^{240} \mathrm{Pu}$ ) in Korean soils or sediments have been investigated mostly through radioecological studies and surveys in terrestrial and marine environments (Lee et al., 1997, 1998, 2012; Park et al., 2004), to assess the environmental impacts of Korean nuclear power plants (NPP) (Cha et al., 2006), to date sediment and evaluate sedimentation in ponds and lakes (Nahm et al., 2010) and to evaluate the radioactive fallout associated with the recent accident of the Fukushima NPP (Hong et al., 2012; Kim et al., 2012). However the use of FRN and especially ${ }^{137} \mathrm{Cs}$ as a soil erosion tracer for assessing soil erosion rates is scarce in Korea (Menzel et al., 1987). ${ }^{137} \mathrm{Cs}$ is an anthropogenic isotope produced from the testing of thermonuclear weapons during the 1950s and 1960s. When ${ }^{137} \mathrm{Cs}$ fallout reaches the soil surface, it is tightly adsorbed to fine soil particles (Tamura, 1964; Tamura and Jacobs, 1960) and its subsequent redistribution is associated with soil erosion (Ritchie and McHenry, 1990). The ${ }^{137} \mathrm{Cs}$ 
method has the major advantage of integrating different erosion processes over a time span of several decades (Mabit et al., 2008a). However, the method has also some pitfalls (Mabit et al., 2008b, 2013; Parsons and Foster, 2011). Assessment of soil redistribution rates is commonly based on a comparison of the ${ }^{137} \mathrm{Cs}$ inventory (areal activity density) at individual points in the landscape with that of "stable" landscape position (also termed reference site), where neither erosion nor deposition has occurred. One of the most critical aspects of the ${ }^{137} \mathrm{Cs}$ method is the identification of undisturbed reference sites that allows the evaluation of the initial fallout. The latter has been shown to be connected to small-scale variability (Sutherland, 1996).

The stable isotope composition of a soil profile can provide valuable information on the disturbance or nondisturbance of a potential reference site. Stable isotopes of organic carbon (i.e. $\delta^{13} \mathrm{C}$ ) and nitrogen (i.e. $\delta^{15} \mathrm{~N}$ ) served as useful tools to determine sources and sinks of carbon, nitrogen or sediments (Alewell et al., 2008; Buck and Monger, 1999; Papanicolaou et al., 2003; Schaub and Alewell, 2009; Turnbull et al., 2008; Fox and Papanicolaou, 2007; Jacinthe et al., 2009). They are also useful for process identification and even process quantification (Conen et al., 2007, 2008). More recently, stable carbon isotopes have been used to track soil erosion and wetland degradation (Alewell et al., 2011; Schaub and Alewell, 2009). The latter studies were the first to show that isotope patterns reflect degradation processes such as soil erosion or wetland drainage. In the Swiss Central Alps a close correlation of $\delta^{13} \mathrm{C}$ and carbon content $(r>0.80)$ was found for oxic upland soils that were not affected by soil erosion, indicating that depth profiles of $\delta^{13} \mathrm{C}$ mainly reflect decomposition of soil organic carbon (SOC; Schaub and Alewell, 2009). Long-term disturbance of upland soils was indicated by decreasing correlation of $\delta^{13} \mathrm{C}$ and SOC $(r<0.80)$, which went in parallel with increasing (visible) degradation at the investigated site. The degree of degradation, which in our case is the soil erosion rate, will be assessed by the ${ }^{137} \mathrm{Cs}$ method and with an additional independent method: the Revised Universal Soil Loss Equation (RUSLE) (Renard et al., 1997). RUSLE is one of the most widely used soil erosion models (Kinnell, 2010). Even though it is an empirical model it proved to be useful for soil erosion quantification in very different environments as well as in Korea (Park et al., 2011, 2012; Yoon et al., 2009).

The aim of this study is to apply the method of Schaub and Alewell (2009) to forested mountain soils in Korea with the purpose of using, in addition to the carbon stable isotopes, the nitrogen stable isotope as an indicator for soil disturbance. The sites indicated as undisturbed by the stable isotope approach will be subsequently used as reference site for soil erosion quantification with the ${ }^{137} \mathrm{Cs}$ method. The ${ }^{137} \mathrm{Cs}-$ based erosion rates will be further compared to the modeled soil erosion rates with RUSLE.

\section{Materials and method}

\subsection{Description of the Haean basin and the experimental site}

The study site is located in the bowl-shaped mountain catchment of Haean (Fig. 1), 1-2 km south of the demilitarized zone (DMZ), South Korea $\left(38^{\circ} 15^{\prime} \mathrm{N}, 128^{\circ} 15^{\prime} \mathrm{E}\right)$. The steep, surrounding mountain ridges of up to $1320 \mathrm{~m}$ a.s.l. are of metamorphic rock (Kwon et al., 1990) mainly forming acidic and podzolic Cambisols (classified according to WRB; IUSS, 2006). The parent material in the flat to moderately steep basin bottom ( $340 \mathrm{~m}$ a.s.l) consists of highly weathered biotite granites with Anthroposols and Arenosols as predominant soil types.

The Haean basin lies in a temperate climate region. Mean annual precipitation recorded at the Nae-myun weather station, located $5.2 \mathrm{~km}$ away from the study site, is $1453 \pm 37 \mathrm{~mm}$ (1997-2009), whereof $45 \%$ of the annual rainfall occurs in June and July, associated with the Asian monsoon (Jung et al., 2012). The mean annual temperature is $7.8^{\circ} \mathrm{C}$ (1997-2009). The Haean basin is an intensively used headwater catchment of the Lake Soyang reservoir. During the last decades, the rapid agricultural expansion and intensification transformed large areas of hill slope forests into paddies and vegetable fields, which formerly were found only at the basin bottom. Still $58 \%$ of the Haean catchment (mainly the steep mountain ridges) are stocked with mixed deciduous forests aged about 30-40 yr (Jung et al., 2012). The intensive agriculture along with the easily erodible soils at the basin bottom constitutes the major source of suspended sediment to the drinking water reservoir Lake Soyang, which provides the drinking water supply for over ten million people in Seoul (Jung et al., 2012). For more details about the Haean basin the reader is referred to Jeong et al. (2012) and Jung et al. (2012).

In the northern part of the Haean catchment we choose a forested site valley for our study (Fig. 1). One sampling transect with five sampling points was located at the southeastexposed slope, a second one with five sampling points at the opposite west-exposed slope. One reference location was chosen on the ridge top of the southeast-exposed slope (reference 1); a second one was located as well on a flat forested ridge top (reference 2). The forest is dominated by Mongolica oaks (Quercus mongolica), Daimyo oaks (Quercus dentata), and Korean ashes (Fraxinus rhynchophylla). The undergrowth is scarce, however with a dense litter cover and moder-like $\mathrm{O}$ horizons. In this forested mountain site we typically find acidic Cambisols with a silty sand soil texture and a high skeleton content $(>2 \mathrm{~mm}$ ) amounting approximately $30 \%$ of the total soil weight. 


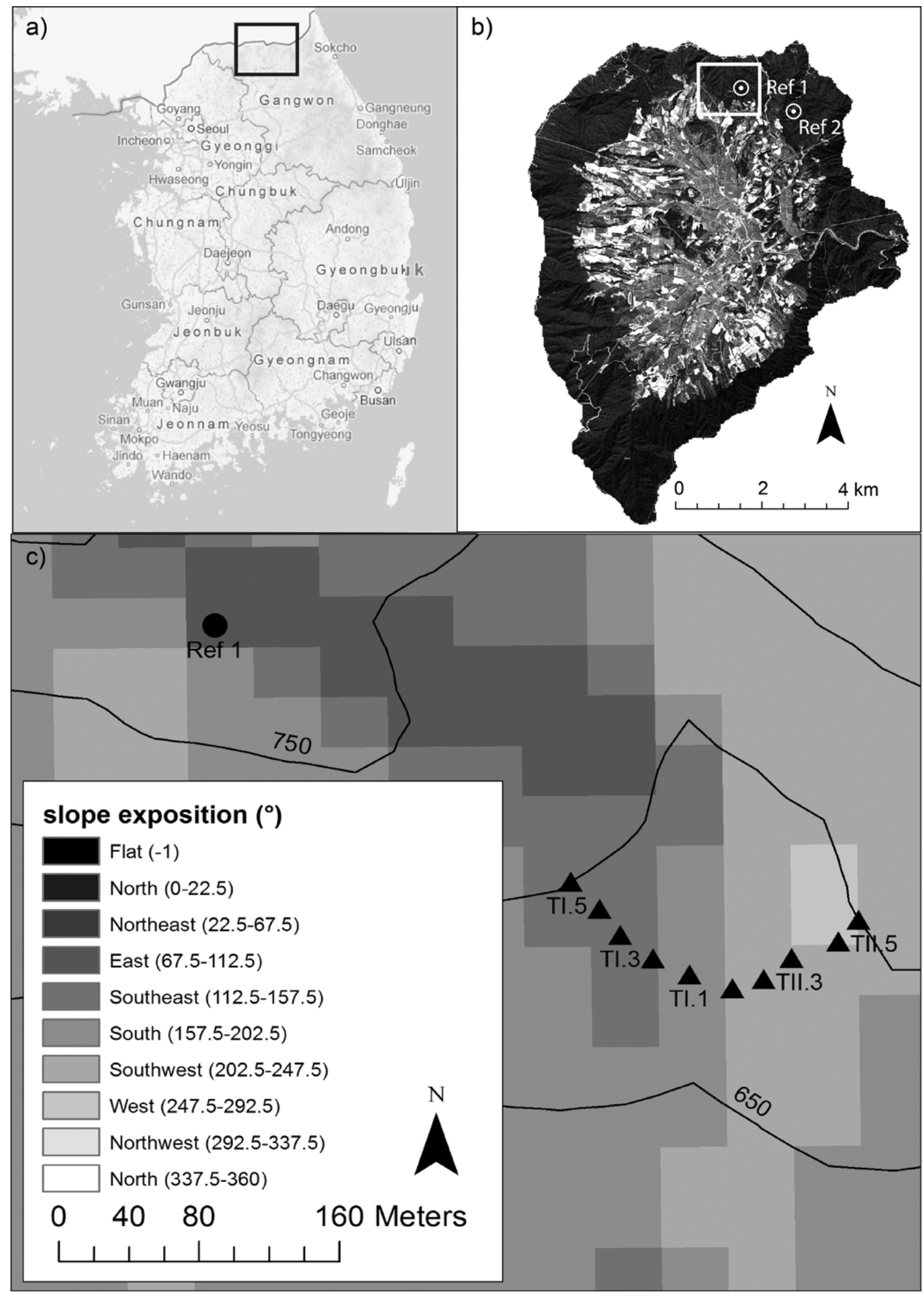

Fig. 1. Location of the study area on the Korean peninsula (a) and within the Haean catchment with the location of the reference sites (Ref 1, Ref 2) (b) and the sampling points of the soil erosion transects (TI.1-5 and TII.1-5) (c). 


\subsection{Soil sampling and preparation}

In April 2010 soil samples were collected at steep forested slope transects and two reference sites, which were respectively located within $0.25 \mathrm{~km}$ and $1.8 \mathrm{~km}$ of the sampling sites (Fig. 1). At each sampling point, soil cores were taken until bedrock (on average $30 \mathrm{~cm}$ for reference site 1 and 45 $\mathrm{cm}$ for reference site 2) with a soil corer (Giddings Machine Company, Windsor, CO, USA). The soil cores were used to determine the bulk densities and the section mass weight of the samples. The selection of the reference site to estimate the initial ${ }^{137} \mathrm{Cs}$ fallout is an important step. We selected two flat forested ridge tops located in the vicinity of the sampling sites, which had not been subjected to any human disturbance. Buried land mines from the Korean War still exist in the area. Therefore, sampling was limited to sites known to be free of mines. It is generally agreed that for the estimation of the initial ${ }^{137} \mathrm{Cs}$ at least ten samples are needed (Sutherland, 1996). We took twelve reference soil profiles. For six reference profiles, samples were analyzed in $3 \mathrm{~cm}$-depth increments. The remaining profiles of the reference site were treated as bulk samples. Along each slope transect we took cores at five locations (approximately $30 \mathrm{~m}$ apart) according to slope topography. For the soil profiles of the transect samples, at least 5 depth increments were kept for stable isotope analysis. The potential erosional transects were located on slopes oriented west (transect I) and southeast (transect II) of a small forest stream.

Soil samples were oven-dried at $40^{\circ} \mathrm{C}$, passed through a $2 \mathrm{~mm}$ sieve and homogenized. The fine material $(<2 \mathrm{~mm})$ was used for all further analysis. Total organic and inorganic carbon concentration (\%) was measured by the RC612 Multiphase Carbon and Hydrogen/Moisture Analyzer (Leco company, MI, USA). Organic matter was calculated from organic carbon content by using the conversion factor of 1.72 .

\subsection{Stable isotope analysis}

As even small amounts of inorganic carbon can give significant errors in $\delta^{13} \mathrm{C}$, inorganic carbon was removed prior to stable isotope analysis by acid fumigation following the method of Harris et al. (2001). Moistened subsamples were exposed to the exhalation of $\mathrm{HCl}$ in a desiccator overnight. Afterwards, the samples were dried at $40^{\circ} \mathrm{C}$ before measuring the stable isotope ratio. The $\mathrm{N}$ measurements were done with unacidified samples. The stable $\mathrm{N}$ isotope ratios and the $\mathrm{C}$ and $\mathrm{N}$ concentrations were measured by isotope ratio mass spectrometry (Thermo Finnigan Delta plus XP coupled with a Flash EA 1112 Series elemental analyzer; both instruments supplied by Thermo-Finnigan, Waltham, MA, USA). The instrumental standard deviation for $\delta^{15} \mathrm{~N}$ is $0.15 \%$ and $0.1 \%$ for $\delta^{13} \mathrm{C}$. Stable isotopes are reported as delta values (\%o), which are the differences between sample readings and natural abundance standards (e.g. $\delta^{15} \mathrm{~N}=$ zero for air).

\section{$2.4 \quad{ }^{137} \mathrm{Cs}$ analysis and estimation of soil erosion rates}

The activities of ${ }^{137} \mathrm{Cs}$ in soil samples were determined by gamma spectrometry using a "N"-type high-purity germanium detector (30\% relative efficiency; energy range 20 $2000 \mathrm{keV}$ ) shielded with $10 \mathrm{~cm}$ lead and $3 \mathrm{~mm}$ copper. The counting time for each sample was set at $80000 \mathrm{~s}$ to reach an acceptable level of detection limit and to reach a measurement error under $10 \%$ at $2 \sigma$ precision. Calibration of equipment, analysis and quality control of the measurements were performed following IAEA standard procedure (Shakhashiro and Mabit, 2009).

The areal activity $\left(\mathrm{Bq} \mathrm{m}^{-2}\right)$ was calculated from ${ }^{137} \mathrm{Cs}$ activities $\left(\mathrm{Bq} \mathrm{kg}^{-1}\right)$ multiplying the mass of each increment sample. The total inventory was calculated as the sum of the depth intervals areal activity over the soil profile $(0 \mathrm{~cm}$ to bedrock) divided by the sampling device area.

The soil erosion rates were obtained from ${ }^{137} \mathrm{Cs}$ measurements using the profile distribution conversion model (Walling et al., 2002, 2011). The profile distribution model is most commonly used for natural, non-cultivated soils, where the distribution of ${ }^{137} \mathrm{Cs}$ with soil depth shows an exponential decline that can be described by the following equation (Walling and He, 1999; Zhang et al., 1990):

$A^{\prime}(x)=A_{\text {ref }}\left(1-e^{x / h_{0}}\right)$,

where

$$
\begin{aligned}
A^{\prime}(x)= & \text { amount of }{ }^{137} \mathrm{Cs} \text { above the depth } x\left(\mathrm{~Bq} \mathrm{~m}^{-2}\right) ; \\
x= & \text { depth from soil surface expressed as mass } \\
& \text { between top and actual depth }\left(\mathrm{kg} \mathrm{m}^{-2}\right) \\
A_{\text {ref }}= & { }^{137} \mathrm{Cs} \text { reference inventory }\left(\mathrm{Bq} \mathrm{m}^{-2}\right)
\end{aligned}
$$

and $h_{0}=$ the profile shape factor $\left(\mathrm{kg} \mathrm{m}^{-2}\right)$, which describes the rate of exponential ${ }^{137} \mathrm{Cs}$ decrease with depth. The greater the value of the shape factor $h_{0}$, the deeper ${ }^{137} \mathrm{Cs}$ penetrates into the soil (Walling et al., 1999). The main ${ }^{137} \mathrm{Cs}$ fallout at our site occurred during the peak of the atomic bomb tests in 1963 (Menzel et al., 1987). Thus, the total soil erosion at a point can be expressed as (Walling and He, 1999; Zhang et al., 1990)

$Y=\frac{10}{t-1963} \ln \left(1-\frac{X}{100}\right) h_{0}$,

with $t=$ year of sample collection and $X$ the percentage reduction in total ${ }^{137} \mathrm{Cs}$ inventory.

Further we used the RUSLE model (Renard et al., 1997) to assess soil erosion rates and for comparison to soil erosion rates obtained with the ${ }^{137} \mathrm{Cs}$ method. RUSLE is an empirical model based on the following equation:

$A=R \times K \times L S \times C \times P$, 
where $A$ represents the predicted long-term average annual soil loss in tonnes per hectare per year; $R$ is the rainfall factor; $K$ is the soil erodibility factor; $L$ and $S$ are the slope length and steepness factors, respectively; $C$ is the cropping-management factor; and $P$ is the support practice factor. The $R$ and $L S$ factor were calculated according to Renard et al. (1997). The $R$ factor was estimated with $6600 \mathrm{MJ} \mathrm{mm} \mathrm{ha}{ }^{-1} \mathrm{~h}^{-1} \mathrm{yr}^{-1}$, based on weather data from 1999 to 2011 (Arnhold et al., 2013). This relatively high rainfall erosivity can be attributed to the impact of intensive rainfall events during the Asian monsoon. The $K$ factor $\left(\mathrm{tha} \mathrm{MJ}^{-1} \mathrm{~mm}^{-1}\right.$ ) was estimated for the topsoil layer (upper $10 \mathrm{~cm}$ ) using the following equation (Lal, 1988):

$$
\begin{aligned}
K & =\left(27.66 \times m^{1.14} \times 10^{-8} \times(12-a)\right) \\
& +(0.0043 \times(b-2))+(0.0033 \times(c-3)),
\end{aligned}
$$

where $m$ is calculated as silt $(\%)+$ very fine sand $(\%) \times(100-$ clay (\%)), $a$ is the organic matter content $(\%), b$ defines the structure from particulate (1) to solid (4), where we used fairly structured (2) for all sites and $c$ parameterizes the profile permeability from rapid (1), to very slow (6), where we used a value of 3 corresponding to moderate permeability. Grain size analysis for the parameter $m$ was done with the Malvern Mastersizer 2000 (Malvern Instruments Ltd). Carbon content measurement is described in Sect. 2.2. For the $C$ factor we used a uniform value of $C$ factor $=0.001$ for forested sites (Wischmeier and Smith, 1978). The $P$ factor was neglected because no soil conservation measures have been introduced in this area.

\section{Results and discussion}

\subsection{Carbon and nitrogen stable isotopes as indicators of soil erosion}

Measurement of bulk density showed an increase (from $0.6 \mathrm{~g} \mathrm{~cm}^{-3}$ for the upper depth increment to $1.4 \mathrm{~g} \mathrm{~cm}^{-3}$ for the lower depth increment as averages for the reference soils) with depth as is typically observed for forest soils. Active bioturbation, combined with high enrichment of organic matter and thawing-freezing cycles, might have resulted in lower bulk density in the upper soil horizons.

In order to detect increased and recent erosion, mainly the upper soil horizons were examined. As sheet erosion is a surface process, a change in isotope signature was expected to primarily occur within the top $12 \mathrm{~cm}$ of the soil profile. The carbon isotope signatures of the upper soil horizons tended to be higher in the reference soils than in the erosion plots, with an average of $-25.8 \%$ compared to an average signature of $-26.4 \%$ for the eroded upper soil horizons (Fig. 2). For the lower horizons the difference between the signature of reference soils $(-24.1)$ and the eroding soils $(-25.7)$ was significant $(p=0.01)$. The $\delta^{13} \mathrm{C}$ depth profile showed an increase with depth for both transect and reference samples.

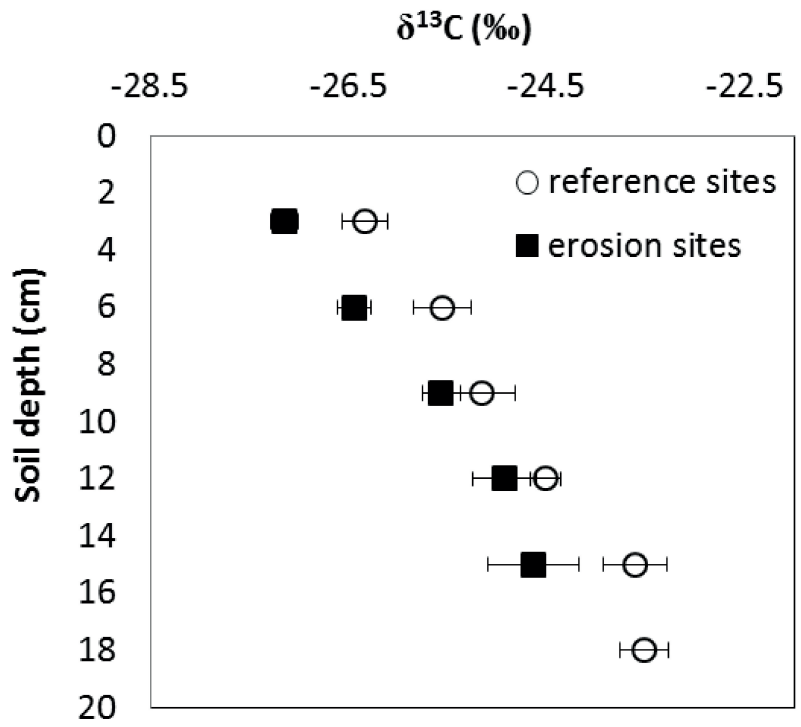

Fig. 2. Vertical distribution of mean $\delta^{13} \mathrm{C}$ for reference sites and sites affected by soil redistribution (error bars express the standard error).

Increasing $\delta^{13} \mathrm{C}$ values with depth are typical for oxic, welldrained soils (Balesdent et al., 1993; Chen et al., 2002; Novak et al., 2003), because aerobic decomposition favors selective loss of ${ }^{12} \mathrm{C}$ (Nadelhoffer and Fry, 1988; Beckerheidmann and Scharpenseel, 1989; Ågren et al., 1996).

Parallel to the depth increase of $\delta^{13} \mathrm{C}$ in undisturbed oxic soils, we usually find a decrease in SOC content, which is also observed for both transect and reference sites. Plotting $\delta^{13} \mathrm{C}$ against $\mathrm{C}$ content resulted in different patterns for the reference and erosion samples. For both of the reference sites we found a highly significant $(p<0.0001)$ correlation between $\delta^{13} \mathrm{C}$ and $\mathrm{C}$ content for the depth-incremental samples of the 3 profiles (Fig. 3, right). Decreases in $\delta^{13} \mathrm{C}$ concurred with decreasing $\mathrm{C}$ contents with increasing soil depth. For the two erosional transects (consisting of 5 depth profiles, each) we did not find a correlation ( $p=0.25$; Fig. 3, left).

In an undisturbed soil $\delta^{13} \mathrm{C}$ is strongly linked to soil carbon content since SOC decomposition is accompanied by isotopic fractionation. During soil erosion SOC is first to go into suspension in the form of small colloidal particles and is preferentially exported (Bilgo et al., 2006; Polyakov and Lal, 2004; Watung et al., 1996). Soil erosion may foster mineralization and leaching of soil organic carbon (Lal, 2003), which results in a shift of $\delta^{13} \mathrm{C}$ values and thus a deviation from the correlation between $\delta^{13} \mathrm{C}$ and $\mathrm{C}$ content of oxic soils. This characteristic was shown to be indicative for enhanced soil degradation (i.e. carbon loss) due to soil erosion for grassland sites in the Swiss Alps (Schaub and Alewell, 2009). The analysis of the Korean mountain soils confirms the applicability of the approach for non-cultivated Korean forest soils. However, the $\delta^{13} \mathrm{C}$ vs. $\mathrm{C}$ content is a qualitative indicator for 
Reference site 1

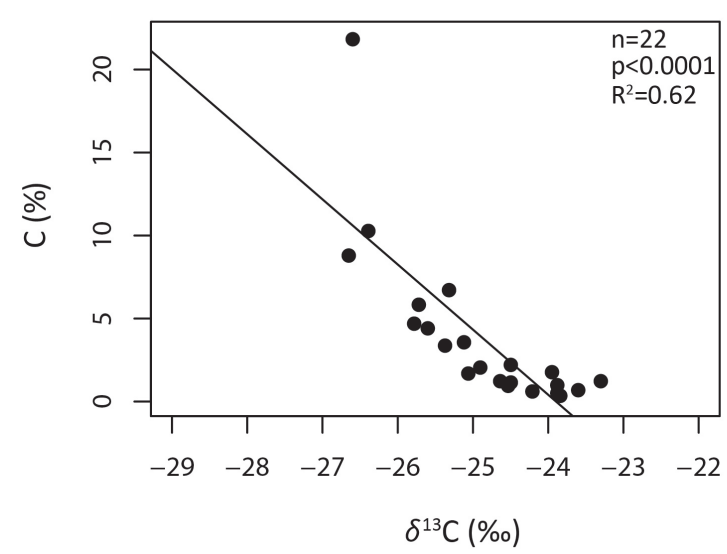

Transect 1

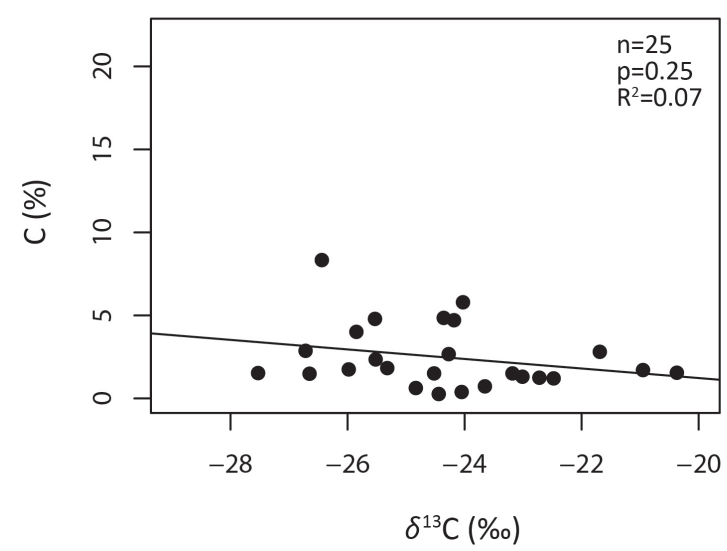

Reference site 2

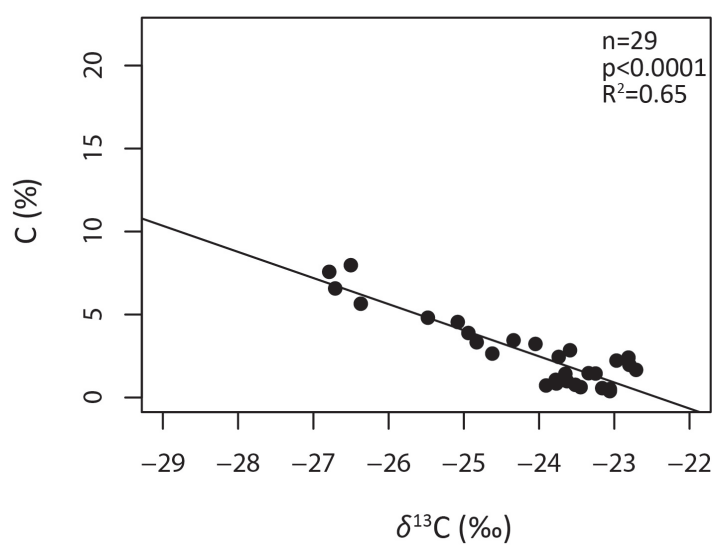

Transect 2

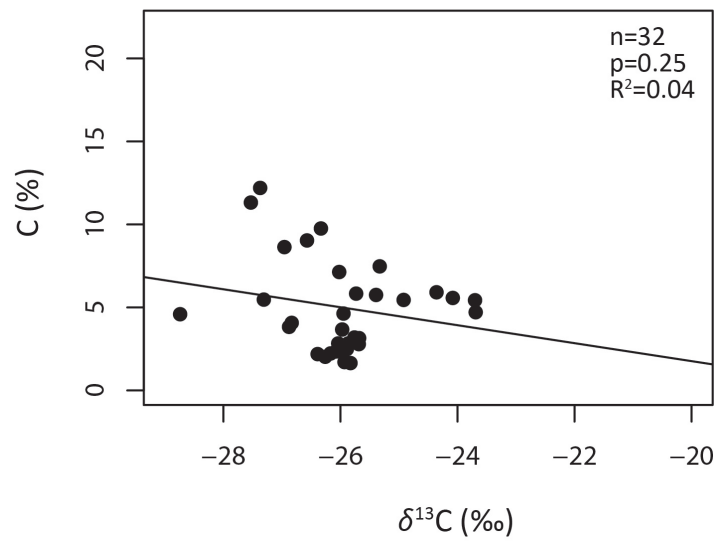

Fig. 3. Relation of carbon content and $\delta^{13} \mathrm{C}$ (n express the number of all depth-incremental samples at particular transects and reference sites).

soil disturbance and not suitable for quantification of soil erosion rates.

The same concept of correlation was applied to assess the suitability of $\delta^{15} \mathrm{~N}$ as a soil erosion tracer. $\delta^{15} \mathrm{~N}$ is enriched with soil depth due to an increasing proportion of microbially altered $\mathrm{N}$ transported downward in the soil profile and also aerobic mineralization (Mariotti et al., 1980). Amundson et al. (2003) hypothesized that $\delta^{15} \mathrm{~N}$ of steeply sloping soils with a short residence time should have $\delta^{15} \mathrm{~N}$ values similar to the atmospheric input due to soil removal (and hence short time for the mentioned isotope fractionation processes to take effect). Thus, the $\delta^{15} \mathrm{~N}$ value is expected to be higher for reference soils with long residence times than for the eroding slope samples. Similar as for the $\delta^{13} \mathrm{C}$ depth profile, the $\delta^{15} \mathrm{~N}$ increased with soil depth as has been reported at many other sites (Mariotti et al., 1980; Nadelhoffer and Fry, 1988; Riga et al., 1971). However, for our samples we could not observe a difference of the average $\delta^{15} \mathrm{~N}$ signature in the topsoil be- tween the reference and the erosion sites (Fig. 4). The difference is mainly masked by negative $\delta^{15} \mathrm{~N}$ values $(-1.37$ to -0.58 ) of reference site 1 with podsolic conditions. Decomposition of litter material is slowed down due to the low $\mathrm{pH}$ values of Podzols, and hardly decomposable parts of plants, e.g. recalcitrant organic substances, may accumulate. The resulting litter and humus material shows a depletion in ${ }^{15} \mathrm{~N}$, which is most likely driven by mycorrhizal fungi providing a major part of $\mathrm{N}$ to the vegetation (Lindahl et al., 2007). Only for the deeper soil layers $(>12 \mathrm{~cm})$ the differences became larger with higher $\delta^{15} \mathrm{~N}$ for the reference site. It is also expected that $\delta^{15} \mathrm{~N}$ of the topsoil layer increases with decreasing erosion rate. However, the comparison of $\delta^{15} \mathrm{~N}$ values of the topsoil layer to soil erosion rates showed no correlation (Fig. 5).

Plotting total nitrogen content $(\%)$ vs. $\delta^{15} \mathrm{~N}$, we found clearly higher correlations with $r^{2}=0.79$ and $r^{2}=0.67$ for both reference sites than for the erosion sites $\left(r^{2}\right.$ is $0.27,0.31$, 


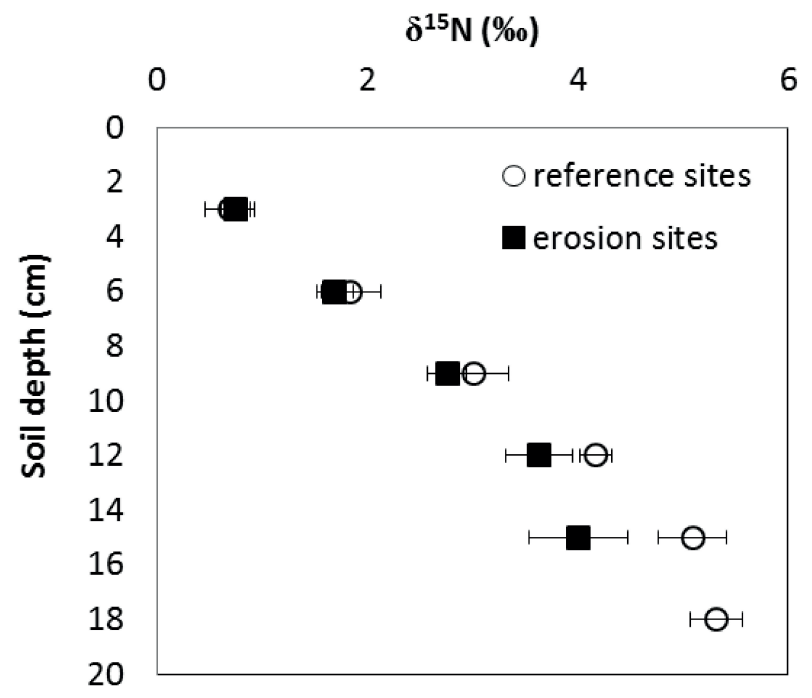

Fig. 4. Vertical distribution of mean $\delta^{15} \mathrm{~N}$ for reference sites and sites affected by soil redistribution (error bars express the standard error).

respectively, Fig. 6). At reference site 2, some samples plot slightly below the trend line (non-filled dots). These are samples below a soil depth of $21 \mathrm{~cm}$ with a higher sand content resulting in a dilution of $\% \mathrm{~N}$.

The use of $\delta^{15} \mathrm{~N}$ signature of the topsoil as a soil erosion indicator as proposed by Amundson (2003) is ambiguous. Stable soils are expected to have higher $\delta^{15} \mathrm{~N}$ signatures due to a longer time interval in which decomposition could foster fractionation. However, for stable soils with organic horizons, where decomposition is stopped due to e.g. acidic conditions, the $\delta^{15} \mathrm{~N}$ signature is negative (Mariotti et al., 1980) even though the soil profile is undisturbed. Hence, the sole use of $\delta^{15} \mathrm{~N}$ as the indicator of soil erosion is restricted to similar soil types with similar humus types. In contrast, the correlation between $\delta^{15} \mathrm{~N}$ and $\% \mathrm{~N}$ for the soil profile appears as a more robust indicator for unfertilized soils.

\subsection{Quantification of soil redistribution}

${ }^{137} \mathrm{Cs}$ activity for the reference sites decreased exponentially with depth (Fig. 7). On average, $45 \%$ of the ${ }^{137}$ Cs activity occurred in the upper $3 \mathrm{~cm}$ and approximately $90 \%$ of the total ${ }^{137} \mathrm{Cs}$ was concentrated in the first $9 \mathrm{~cm}$. The exponential decline of ${ }^{137} \mathrm{Cs}$ with depth could best be approximated by a shape factor $h_{0}$ (see Eq. 1) of 26.8. The variability of ${ }^{137} \mathrm{Cs}$ was highest for the topsoil samples and decreased with depth (Fig. 7).

Two reference cores were excluded for the inventory assessment, as most likely the bedrock was not reached and thus sampling depth was not sufficient to reach low ${ }^{137} \mathrm{Cs}$ activity values for the lowermost sample increment. The ${ }^{137} \mathrm{Cs}$ baseline inventory of the remaining 10 depth-incremental samples was $1607 \pm 292 \mathrm{~Bq} \mathrm{~m}^{-2}$ (cv. of $18 \%$ ) with an al-

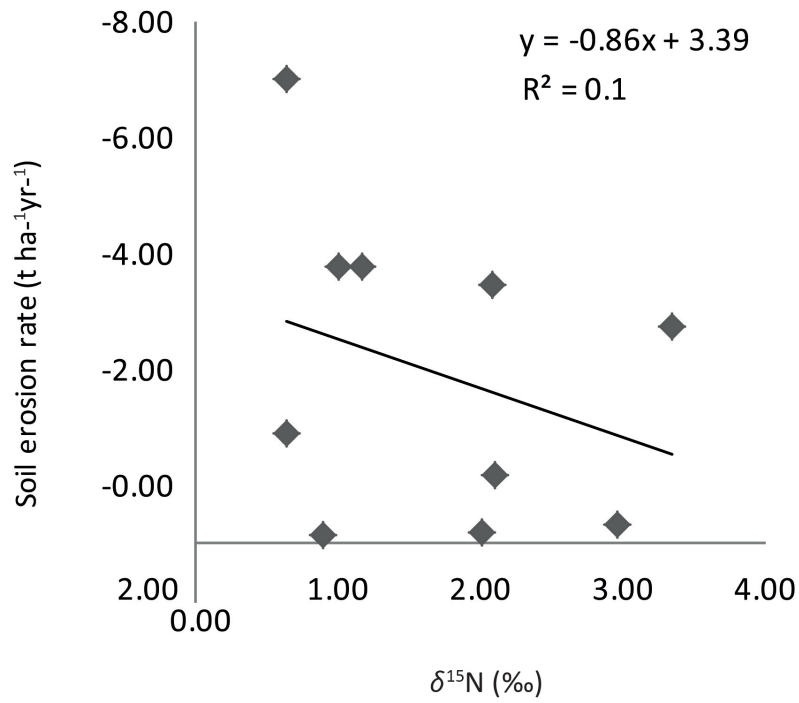

Fig. 5. Transect I and II soil erosion rates vs. $\delta^{15} \mathrm{~N}$ values of the topsoil layer (upper $12 \mathrm{~cm}$ ).

lowable error of $10 \%$ at the $90 \%$ confidence level (Mabit et al., 2010, 2012). The variability of the reference inventories is within the range for forest sites reported by Sutherland (1991, 1996) and Owen and Walling (1996). In addition, using the average annual precipitation of the area and based on Walling et al. $(2002,2011)$ the initial ${ }^{137} \mathrm{Cs}$ atmospheric fallout can be estimated at around $1620 \mathrm{~Bq} \mathrm{~m}^{-2}$. Moreover, the inventory is also within the expected range of values assessed in a previous ${ }^{137} \mathrm{Cs}$ study on soil erosion in South Korea (Menzel et al., 1987). This study, conducted in 1986, provided ${ }^{137} \mathrm{Cs}$ reference inventories for 4 sites that ranged between $2059 \mathrm{~Bq} \mathrm{~m}^{-2}$ and $4958 \mathrm{~Bq} \mathrm{~m}^{-2}$ with an average value of $3541 \mathrm{~Bq} \mathrm{~m}^{-2}$. Thus, after $24 \mathrm{yr}$ of decay, inventories of $1133-2728 \mathrm{~Bq} \mathrm{~m}^{-2}$ can be expected for the different regions in 2010. The site investigated by Menzel et al. (1987), which is most similar to our site with respect to land cover and annual precipitation, is the Suweon site, a grassy pine grove (location: $37^{\circ} 15^{\prime} \mathrm{N}, 126^{\circ} 50^{\prime} \mathrm{E}$; annual mean precipitation $\left.=1328 \mathrm{~mm} \mathrm{yr}^{-1}\right)$. The mean ${ }^{137} \mathrm{Cs}$ fallout value for three investigated reference sites in Suweon $\left(3424 \mathrm{~Bq} \mathrm{~m}^{-2}\right.$ measured in 1986 representing $1884 \mathrm{~Bq} \mathrm{~m}^{-2}$ after decay correction for 2010) is within the confidence interval of our estimated reference value.

The ${ }^{137} \mathrm{Cs}$ inventories of the two forested hill slope transects ranged from $516 \mathrm{~Bq} \mathrm{~m}^{-2}$ to $1831 \mathrm{~Bq} \mathrm{~m}^{-2}$ with a mean value of $1258 \mathrm{~Bq} \mathrm{~m}^{-2}(n=10)$. Except for three points, the locations showed reduced ${ }^{137} \mathrm{Cs}$ values relative to the background fallout (Table 1). The average soil redistribution rates resulting from the conversion model for the different slope locations ranged between a sedimentation rate of $0.9 \mathrm{tha}^{-1} \mathrm{yr}^{-1}$ and an erosion rate of $7 \mathrm{tha}^{-1} \mathrm{yr}^{-1}$. The average net erosion rate for transect $\mathrm{I}$ is $1.7 \mathrm{tha}^{-1} \mathrm{yr}^{-1}$ and $2.2 \mathrm{tha}^{-1} \mathrm{yr}^{-1}$ for transect II. The soils of transect II have an 
Table 1. Soil redistribution rates (erosion represented by negative values and accumulation by positive values) estimated for sampled points of transect I (T I) and transect II (T II) by the ${ }^{137}$ Cs method (using the Profile Distribution Model) and RUSLE.

\begin{tabular}{lrrrrrrrr}
\hline Sample & $\begin{array}{r}{ }^{137} \mathrm{Cs} \\
\text { inventory } \\
\left(\mathrm{Bq} \mathrm{m}^{-2}\right)\end{array}$ & $\begin{array}{r}{ }^{137} \text { Cs-based soil } \\
\text { redistribution rates } \\
\left(\mathrm{t} \mathrm{ha}^{-1} \mathrm{yr}^{-1}\right)\end{array}$ & $\begin{array}{r}\text { Slope } \\
\text { ength } \\
(\mathrm{m})\end{array}$ & $\begin{array}{r}\text { Slope } \\
\text { angle } \\
\left({ }^{\circ}\right)\end{array}$ & $\begin{array}{r}K \text { factor } \\
\left(\mathrm{t} \mathrm{ha} \mathrm{h} \mathrm{MJ} \mathrm{ha}^{-1} \mathrm{~mm}^{-1}\right)\end{array}$ & $\begin{array}{r}L S \text { factor } \\
(-)\end{array}$ & $\begin{array}{r}\text { RUSLE } \\
\text { estimates } \\
\left(\mathrm{t} \mathrm{ha}^{-1} \mathrm{yr}^{-1}\right)\end{array}$ & $\begin{array}{r}\text { Sampling } \\
\text { depth } \\
\left(\mathrm{cm}^{2}\right)\end{array}$ \\
\hline T I.5 & 917 & -3.5 & 20 & 30 & 0.044 & 17.8 & -2.2 & 51 \\
T I.4 & 1030 & -2.7 & 50 & 30 & 0.044 & 28.2 & -3.4 & 41 \\
T I.3 & 1786 & 0.7 & 85 & 32 & 0.044 & 41.0 & -4.5 & 36 \\
T I.2 & 873 & -3.8 & 102 & 40 & 0.044 & 65.6 & -5.1 & 41 \\
T I.1 & 1814 & 0.8 & 135 & 0 & 0.048 & 0.2 & 0.0 & 42 \\
T II.5 & 516 & -7.0 & 20 & 35 & 0.036 & 23.1 & -1.8 & 26 \\
T II.4 & 1391 & -0.9 & 50 & 35 & 0.036 & 36.5 & -2.8 & 15 \\
T II.3 & 868 & -3.8 & 85 & 30 & 0.036 & 36.8 & -3.7 & 45 \\
T II.2 & 1831 & 0.9 & 105 & 15 & 0.036 & 12.3 & -2.0 & 16 \\
T II.1 & 1558 & -0.2 & 135 & 0 & 0.036 & 0.2 & 0.0 & 24 \\
\hline
\end{tabular}

Reference site 1

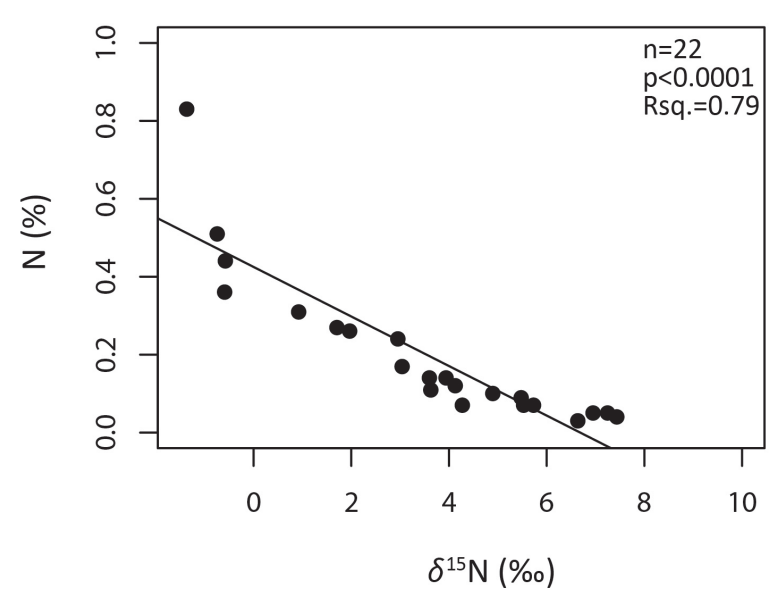

Transect 1

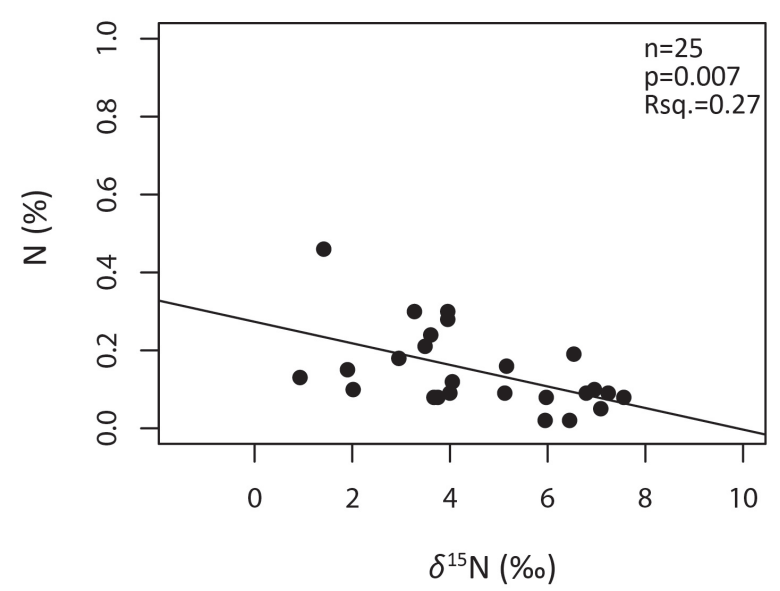

Reference site 2

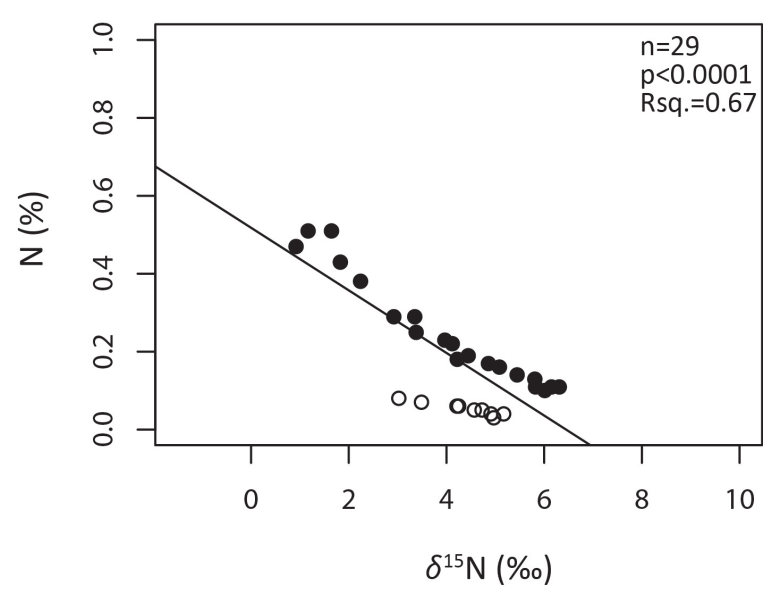

Transect 2

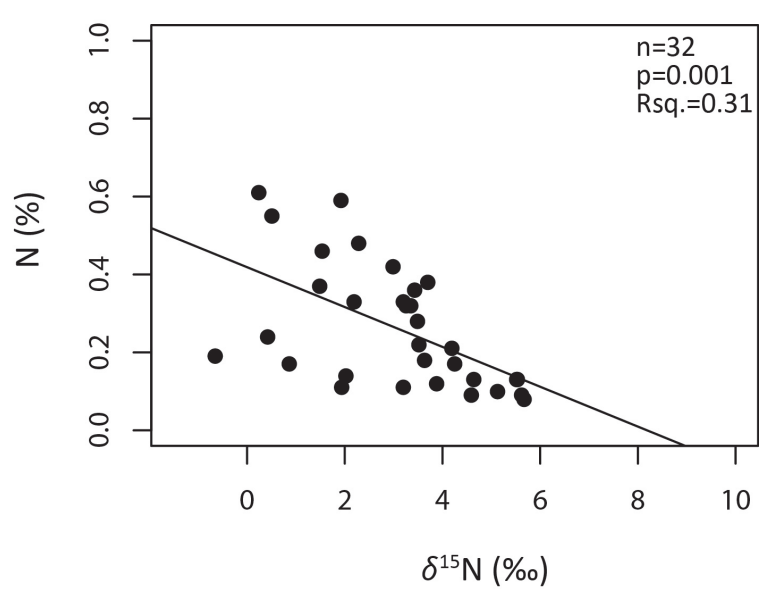

Fig. 6. Relation of total nitrogen content $(\%)$ and $\delta^{15} \mathrm{~N}$ ( $n$ express the number of all depth-incremental samples at particular transects and reference sites). 


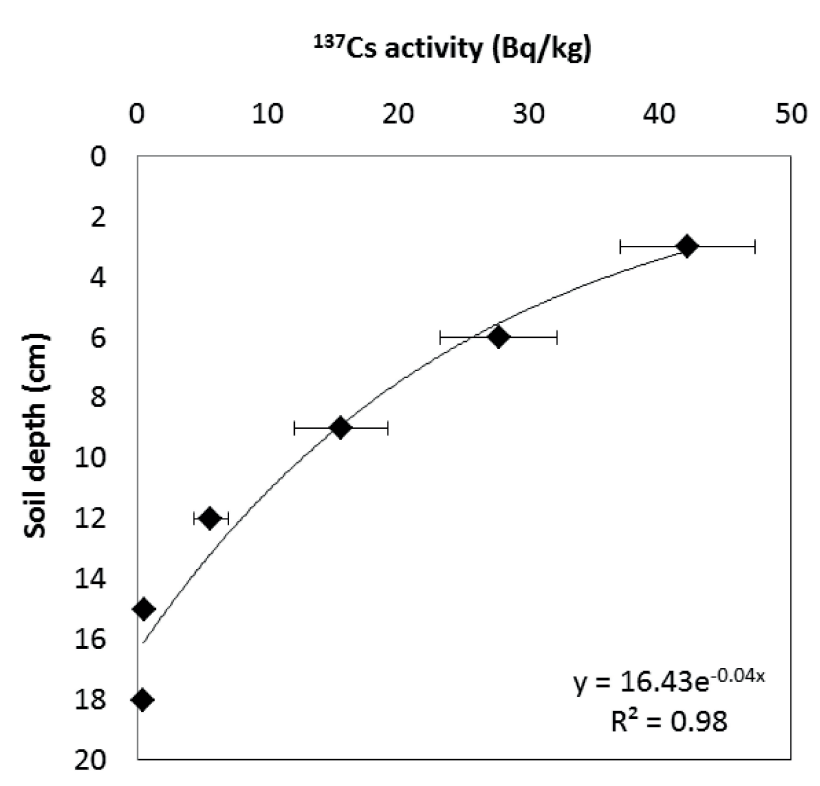

Fig. 7. Average vertical distribution of ${ }^{137} \mathrm{Cs}$ activity $\left(\mathrm{Bq} \mathrm{kg}^{-1}\right)$ in the two reference sites. Error bars indicate standard error (number of samples per depth increment $=6$ ) and the solid line an exponential trend line.

average soil depth of $25.2 \mathrm{~cm}$ compared to $42.2 \mathrm{~cm}$ for transect I.

The relatively small difference in erosion rates between the two slopes might be related to the different exposition. Highest erosion rates can be expected due to monsoon events with prevailing easterly wind directions, which would result in slightly higher erosion rates for the lee slope, which is transect II. Another factor related to exposition is freezingthawing or snowmelt erosion (Park and Woo, 1989), which would also predominantly occur at the southeast slope of transect II.

Soil erosion rates were also quantified using the empirical RUSLE model. The yielded soil erosion estimates are with $0.02 \mathrm{tha}^{-1} \mathrm{yr}^{-1}$ to $5.1 \mathrm{tha}^{-1} \mathrm{yr}^{-1}$ in a comparable magnitude. The average erosion rate for transect $\mathrm{I}$ is $3 \mathrm{tha}^{-1} \mathrm{yr}^{-1}$ and $2.1 \mathrm{tha}^{-1} \mathrm{yr}^{-1}$ for transect II. However, the correlation for the single sampling points is weak $(r=0.26)$ and the difference between transect I and transect II is not reproduced. The erosion rates yielded with the ${ }^{137} \mathrm{Cs}$ method and RUSLE are not directly comparable. First of all, the ${ }^{137} \mathrm{Cs}$ method determines actual net erosion rates as an average since the major nuclear bomb fallout (1963), while the RUSLE simulates long-term average erosion potential of sites mainly due to erosivity of the rain since 1991, actual erodibility of the soil and actual vegetation cover. Furthermore, the ${ }^{137} \mathrm{Cs}$ method provides total net erosion rates of all soil erosion processes involved; the estimates of RUSLE considers solely sheet and rill erosion by water. Thus, RUSLE does not result in a difference of erosion potential of the single transect sites, but is successful in verifying the magnitude of soil erosion rates determined with the ${ }^{137} \mathrm{Cs}$ method. Most likely the RUSLE does not capture the difference between the two transect due to the above-discussed influence of exposition and snow processes. Both transects are subject to a relatively high soil loss for forested sites. On rather flat forested sites one can expect erosion rates of 0.001 to $2 \mathrm{t} \mathrm{ha}^{-1} \mathrm{yr}^{-1}$ (Pimentel, 2006). However, considering the steep slopes and highly erosive monsoon events the obtained average erosion rate for each transect are in a plausible magnitude and compare well to measured plot erosion rates of $0.3-3.4 \mathrm{tha}^{-1} \mathrm{yr}^{-1}$ for another forested site in Korea (Woo, 1984).

\section{Conclusions}

The method proposed by Schaub and Alewell (2009) and Alewell et al. (2011) to use $\delta^{13} \mathrm{C}$ vs. SOC as an indicator for soil erosion and disturbance in uncultivated soils has been tested and validated in the Korean Haean catchment. We could further show that soil depth profiles of $\delta^{15} \mathrm{~N}$ against $\% \mathrm{~N}$ of the soil profile can be used as a soil erosion indicator. The suitability of both stable isotopes should be further evaluated for the potential effects of different soil and humus types and a broader range of soil erosion rates. The ${ }^{137} \mathrm{Cs}$ method yielded relatively high erosion rates for a forest site with $0.9 \mathrm{tha}^{-1} \mathrm{yr}^{-1}$ to $7 \mathrm{tha}^{-1} \mathrm{yr}^{-1}$. However, with respect to the steep slopes investigated and the erosive force of the monsoon events, the rates are plausible and could also be confirmed by the RUSLE-modeled soil erosion rates, which ranged from $0.02 \mathrm{tha}^{-1} \mathrm{yr}^{-1}$ to $5.1 \mathrm{tha}^{-1} \mathrm{yr}^{-1}$. We conclude that soil depth profiles of stable isotopes $\left(\delta^{13} \mathrm{C}\right.$ vs. $\% \mathrm{C}$ and $\delta^{15} \mathrm{~N}$ vs. $\% \mathrm{~N}$ ) may be used as qualitative indicators of soil disturbance. As such they are a suitable tool to confirm the accurate choice of undisturbed reference sites, which is a fundamental requirement for the use of fallout radionuclides in soil erosion studies.

Acknowledgements. The study was supported by the National Research Foundation of Korea through the Strategic Korean-Swiss Cooperative Program. We would like to thank M. Rollog and M. Caroni for the stable isotope, carbon and grain size analysis. Further thanks to one anonymous reviewer and to Fulajtar for their valuable comments.

Edited by: N. Ohte

\section{References}

Ågren, G. I., Bosatta, E., and Balesdent, J.: Isotope discrimination during decomposition of organic matter: A theoretical analysis, Soil Sci. Soc. Am. J., 60, 1121-1126, 1996.

Alewell, C., Meusburger, K., Brodbeck, M., and Bänninger, D.: Methods to describe and predict soil erosion in mountain regions, Landscape Urban Plan., 88, 46-53, 2008.

Alewell, C., Giesler, R., Klaminder, J., Leifeld, J., and Rollog, M.: Stable carbon isotopes as indicators for environmental change 
in palsa peats, Biogeosciences, 8, 1769-1778, doi:10.5194/bg-81769-2011, 2011.

Arnhold, S., Lindner, S., Lee, B., Martin, E., Kettering, J., Nguyen, T. T., Koellner, T., Sik Ok, Y., and Huwe, B.: Conventional and organic farming: soil erosion and conservation potential for row crop cultivation, Geoderma, in review, 2013.

Balesdent, J., Girardin, C., and Mariotti, A.: Site related $\delta^{13} \mathrm{C}$ of tree leaves and soil organic matter in a temperate forest, Ecology, 74, 1713-1721, 1993.

Beckerheidmann, P. and Scharpenseel, H. W.: Carbon Isotope Dynamics in Some Tropical Soils, Radiocarbon, 31, 672-679, 1989.

Bilgo, A., Serpantie, G., Masse, D., Fournier, J., and Hien, V.: Carbon, nitrogen, and fine particles removed by water erosion on crops, fallows, and mixed plots in Sudanese Savannas (Burkina Faso), Soil Erosion and Carbon Dynamics, edited by: Roose, E. J., Lal, R., Feller, C., Barthes, B., and Stewart, B. A., Crc PressTaylor \& Francis Group, Boca Raton, 125-142, 2006.

Buck, B. J. and Monger, H. C.: Stable isotopes and soilgeomorphology as indicators of Holocene climate change, northern Chihuahuan Desert, J. Arid Environ., 43, 357-373, 1999.

Cha, H. J., Kang, M. J., Chung, G. H., Choi, G. S., and Lee, C. W.: Accumulation of Cs-137 in soils on different bedrock geology and textures, J. Radioanal. Nucl. Ch., 267, 349-355, doi:10.1007/s10967-006-0054-4, 2006.

Chen, Q. Q., Shen, C. D., Peng, S. L., Sun, Y. M., Yi, W. X., Li, Z. A., and Jiang, M. T.: Soil organic matter turnover in the subtropical mountainous region of South China, Soil Sci., 167, 401-415, 2002.

Conen, F., Yakutin, M. V., Zumbrunn, T., and Leifeld, J.: Organic carbon and microbial biomass in two soil development chronosequences following glacial retreat, Eur. J. Soil Sci., 58, 758-762, doi:10.1111/j.1365-2389.2006.00864.x, 2007.

Conen, F., Zimmermann, M., Leifeld, J., Seth, B., and Alewell, C.: Relative stability of soil carbon revealed by shifts in $\delta^{15} \mathrm{~N}$ and $\mathrm{C}: \mathrm{N}$ ratio, Biogeosciences, 5, 123-128, doi:10.5194/bg-5-1232008, 2008.

Fox, J. F. and Papanicolaou, A. N.: The use of carbon and nitrogen isotopes to study watershed erosion processes, J. Am. Water Resour. Assoc., 43, 1047-1064, doi:10.1111/j.17521688.2007.00087.x, 2007.

Hong, G. H., Hernaacutendez-Ceballos, M. A., Lozano, R. L., Kim, Y. I., Lee, H. M., Kim, S. H., Yeh, S. W., Boliacutevar, J. P., and Baskaran, M.: Radioactive Impact in South Korea from the Damaged Nuclear Reactors in Fukushima: Evidence of long and Short Range Transport, J. Radiol. Prot., 32, 397-411, doi:10.1088/0952-4746/32/4/397, 2012.

IUSS: Tech. Rep., World reference base for soil resources, FAO, 2006.

Jacinthe, P. A., Lal, R., and Owens, L. B.: Application of stable isotope analysis to quantify the retention of eroded carbon in grass filters at the North Appalachian experimental watersheds, Geoderma, 148, 405-412, doi:10.1016/j.geoderma.2008.11.013, 2009.

Jeong, J. J., Bartsch, S., Fleckenstein, J. H., Matzner, E., Tenhunen, J. D., Lee, S. D., Park, S. K., and Park, J. H.: Differential storm responses of dissolved and particulate organic carbon in a mountainous headwater stream, investigated by high-frequency, in situ optical measurements, J. Geophys. Res.-Biogeo., 117, G03013, doi:10.1029/2012jg001999, 2012.
Jung, B.-J., Lee, H.-J., Jeong, J.-J., Owen, J., Kim, B., Meusburger, K., Alewell, C., Gebauer, G., Shope, C., and Park, J.-H.: Storm pulses and varying sources of hydrologic carbon export from a mountainous watershed, J. Hydrol., 440-441, 90-101, doi:10.1016/j.jhydrol.2012.03.030, 2012.

Kim, C. G., Shin, K., Joo, K. Y., Lee, K. S., Shin, S. S., and Choung, Y.: Effects of soil conservation measures in a partially vegetated area after forest fires, Sci. Total Environ., 399, 158-164, doi:10.1016/j.scitotenv.2008.03.034, 2008.

Kim, C. K., Byun, J. I., Chae, J. S., Choi, H. Y., Choi, S. W., Kim, D. J., Kim, Y. J., Lee, D. M., Park, W. J., Yim, S. A., and Yun, J. Y.: Radiological impact in Korea following the Fukushima nuclear accident, J. Environ. Radioactiv., 111, 70-82, doi:10.1016/j.jenvrad.2011.10.018, 2012.

Kinnell, P. I. A.: Event soil loss, runoff and the Universal Soil Loss Equation family of models: A review, J. Hydrol., 385, 384-397, doi:10.1016/j.jhydrol.2010.01.024, 2010.

Lal, R.: Erodibility and erosivity, in: Soil erosion research methods, edited by: Lal, R., Soil and Water Conservation Society, Ankeny, Iowa, 1988.

Lal, R.: Soil erosion and the global carbon budget, Environ. Int., 29, 437-450, doi:10.1016/s0160-4120(02)00192-7, 2003.

Lee, M. H., Lee, C. W., and Boo, B. H.: Distribution and characteristics of Pu-239, Pu-240 and Cs-137 in the soil of Korea, J. Environ. Radioactiv., 37, 1-16, doi:10.1016/s0265-931x(96)00080-x, 1997.

Lee, M. H., Lee, C. W., Moon, D. S., Kim, K. H., and Boo, B. H.: Distribution and inventory of fallout $\mathrm{Pu}$ and $\mathrm{Cs}$ in the sediment of the East Sea of Korea, J. Environ. Radioactiv., 41, 99-110, doi:10.1016/s0265-931x(98)00011-3, 1998.

Lee, S.: Soil erosion assessment and its verification using the Universal Soil Loss Equation and Geographic Information System: A case study at Boun, Korea, Environ. Geol., 45, 457-465, doi:10.1007/s00254-003-0897-8, 2004.

Lee, S.-H., Lee, S.-A., Lee, J.-M., Park, T.-S., and Lee, K. B.: Measurement of ${ }^{137} \mathrm{Cs}$ in the soil in Korea by low-level background gamma-ray spectrometer, J. Radioanal. Nucl. Ch., 296, 721-725, doi:10.1007/s10967-012-2031-4, 2012.

Lindahl, B. D., Ihrmark, K., Boberg, J., Trumbore, S. E., Hogberg, P., Stenlid, J., and Finlay, R. D.: Spatial separation of litter decomposition and mycorrhizal nitrogen uptake in a boreal forest, New Phytol., 173, 611-620, doi:10.1111/j.14698137.2006.01936.x, 2007.

Mabit, L., Benmansour, M., and Walling, D. E.: Comparative advantages and limitations of the fallout radionuclides $\mathrm{Cs}-137, \mathrm{~Pb}-210$ (ex) and $\mathrm{Be}-7$ for assessing soil erosion and sedimentation, J. Environ. Radioactiv., 99, 1799-1807, doi:10.1016/j.jenvrad.2008.08.009, 2008a.

Mabit, L., Bernard, C., Makhlouf, M., and Laverdiere, M. R.: Spatial variability of erosion and soil organic matter content estimated from Cs-137 measurements and geostatistics, Geoderma, 145, 245-251, doi:10.1016/j.geoderma.2008.03.013, 2008b.

Mabit, L., Martin, P., Jankong, P., Toloza, A., Padilla-Alvarez, R., and Zupanc, V.: Establishment of control site baseline data for erosion studies using radionuclides: a case study in East Slovenia, J. Environ. Radioactiv., 101, 854-863, doi:10.1016/j.jenvrad.2010.05.008, 2010.

Mabit, L., Chhem-Kieth, S., Toloza, A., Vanwalleghem, T., Bernard, C., Amate, J. I., de Molina, M. G., and Gomez, J. A.: Ra- 
dioisotopic and physicochemical background indicators to assess soil degradation affecting olive orchards in southern Spain, Agr. Ecosyst. Environ., 159, 70-80, doi:10.1016/j.agee.2012.06.014, 2012.

Mabit, L., Meusburger, K., Fulajtar, E., and Alewell, C.: The usefulness of ${ }^{137} \mathrm{Cs}$ as a tracer for soil erosion assessment: A critical reply to Parsons and Foster (2011), Earth-Sci. Rev., in press, doi:10.1016/j.earscirev.2013.05.008, 2013.

Mariotti, A., Mariotti, F., Amarger, N., Pizelle, G., Ngambi, J. M., Champigny, M. L., and Moyse, A.: Nitrogen isotope fractionationuring nitrate absorption and atmospheric nitrogen-fixation by plants, Physiol. Veg., 18, 163-181, 1980.

Menzel, R. G., Jung, P. K., Ryu, K. S., and Um, K. T.: Estimating soil-erosion losses in Korea with fallout Cesium-137, Appl. Radiat. Isotopes, 38, 451-454, 1987.

Nadelhoffer, K. F. and Fry, B.: Controls on natural N-15 and C-13 abundances in forest soil organic-matter, Soil Sci. Soc. Am. J., 52, 1633-1640, 1988.

Nahm, W. H., Lee, G. H., Yang, D. Y., Kim, J. Y., Kashiwaya, K., Yamamoto, M., and Sakaguchi, A.: A 60-year record of rainfall from the sediments of Jinheung Pond, Jeongeup, Korea, J. Paleolimn., 43, 489-498, doi:10.1007/s10933-009-9345-4, 2010.

Novak, M., Buzek, F., Harrison, A. F., Prechova, E., Jackova, I., and Fottova, D.: Similarity between C, N and S stable isotope profiles in European spruce forest soils: implications for the use of delta S-34 as a tracer, Appl. Geochem., 18, 765-779, 2003.

Papanicolaou, A. N., Fox, J. F., and J., M.: Soil fingerprinting in the Palouse Basin, USA using stable carbon and nitrogen isotopes, Int. J. Sediment Res., 18, 278-284, 2003.

Park, G., Lin, X. J., Kim, W., Kang, H. D., Lee, H. L., Kim, Y., Doh, S. H., Kim, D. S., Yun, S. G., and Kim, C. K.: Properties of Cs-137 in marine sediments off Yangnam, Korea, J. Environ. Radioactiv., 77, 285-299, 2004.

Park, J. H. and Woo, B. M.: Studies on freezing-thawing erosion from slopes, Seoul National University, J. Agr. Sci., 14, 9-16, 1989.

Park, S., Oh, C., Jeon, S., Jung, H., and Choi, C.: Soil erosion risk in Korean watersheds, assessed using the revised universal soil loss equation, J. Hydrol., 399, 263-273, doi:10.1016/j.jhydrol.2011.01.004, 2011.

Park, S. D., Lee, K. S., and Shin, S. S.: Statistical Soil Erosion Model for Burnt Mountain Areas in Korea-RUSLE Approach, J. Hydrol. Eng., 17, 292-304, doi:10.1061/(asce)he.19435584.0000441, 2012.

Parsons, A. J. and Foster, I. D. L.: What can we learn about soil erosion from the use of ${ }^{137} \mathrm{Cs}$ ?, Earth-Sci. Rev., 108, 101-113, doi:10.1016/j.earscirev.2011.06.004, 2011.

Pimentel, D.: Soil erosion: A food and environmental threat, Environ. Dev. Sust., 8, 119-137, doi:10.1007/s10668-005-1262-8, 2006.

Polyakov, V. O. and Lal, R.: Soil erosion and carbon dynamics under simulated rainfall, Soil Sci., 169, 590-599, doi:10.1097/01.ss.0000138414.84427.40, 2004.

Renard, K. G., Foster, G. R., and Weesies, G. A.: Predicting soil erosion by water; a guide to conservation planning with the revised universal soil loss equation (RUSLE), Agriculture Handbook No. 703, USDA-ARS, 404 pp., 1997.
Riga, A., Vanpraag, H. J., and Brigode, N.: Natural isotope ratios in some forest and agricultural soils in Belgium subjected to various fertility treatments, Geoderma, 6, 213-222, 1971.

Ritchie, J. C. and McHenry, J. R.: Application of radioactive fallout Cesium-137 for measuring soil-erosion and sediment accumulation rates and patterns - a review, J. Environ. Qual., 19, 215-233, 1990.

Schaub, M. and Alewell, C.: Stable carbon isotopes as an indicator for soil degradation in an alpine environment (Urseren Valley, Switzerland), Rapid Commun. Mass Sp., 23, 1499-1507, doi:10.1002/rcm.4030, 2009.

Shakhashiro, A. and Mabit, L.: Results of an IAEA intercomparison exercise to assess $137 \mathrm{Cs}$ and total $210 \mathrm{~Pb}$ analytical performance in soil, Appl. Radiat. Isotopes, 67, 139-146, 2009.

Sutherland, R. A.: Cesium-137 and sediment budgeting within a partially closed drainage-basin, Z. Geomorphol., 35, 47-63, 1991.

Sutherland, R. A.: Caesium-137 soil sampling and inventory variability in reference locations: A literature survey, Hydrol. Process., 10, 43-53, 1996.

Tamura, T.: Selective sorption reactions of cesium with soil minerals, Nucl. Saf., 5, 262-268, 1964.

Tamura, T. and Jacobs, D. G.: Structural implications in cesium sorption, Health Phys., 2, 391-398, doi:10.1097/00004032195910000-00009, 1960.

Turnbull, L., Brazier, R. E., Wainwright, J., Dixon, L., and Bol, R.: Use of carbon isotope analysis to understand semi-arid erosion dynamics and long-term semi-arid land degradation, Rapid Commun. Mass Sp., 22, 1697-1702, doi:10.1002/rcm.3514, 2008.

Walling, D. E. and He, Q.: Improved models for estimating soil erosion rates from cesium-137 measurements, J. Environ. Qual., 28, 611-622, 1999.

Walling, D. E., He, Q., and Blake, W.: Use of Be-7 and Cs-137 measurements to document short- and medium-term rates of waterinduced soil erosion on agricultural land, Water Resour. Res., 35, 3865-3874, 1999.

Walling, D. E., He, Q., and Appleby, P. G.: Conversion models for use in soil-erosion, soil-redistribution and sedimentation investigations, in: Handbook for the Assessment of Soil Erosion and Sedimentation using Environmental Radionuclides, edited by: Zapata, F., the Netherlands, 111-164, 2002.

Walling, D. E., Zhang, Y., and He, Q.: Models for deriving estimates of erosion and deposition rates from fallout radionuclide (caesium-137, excess lead-210, and beryllium-7) measurements and the development of user friendly software for model implementation, in: Impact of Soil Conservation Measures on Erosion Control and Soil Quality, 11-33, 2011.

Watung, R. L., Sutherland, R. A., and ElSwaify, S. A.: Influence of rainfall energy flux density and antecedent soil moisture content on splash transport and aggregate enrichment ratios for a Hawaiian Oxisol, Soil Technol., 9, 251-272, doi:10.1016/s09333630(96)00003-7, 1996.

Wischmeier, W. H. and Smith, D. D.: Predicting Rainfall Erosion Losses - A Guide to Conservation Planning, Agr. Handbook No. 537, Washington DC, 58, 1978.

Woo, B. M.: Integrated analytical study of runoff rate and soil loss measurement in experiments from forest lands in Korea, Agricultural Research Seoul National University, 9, 11-18, 1984. 
Woo, B. M., Park, J.-H., Jeon, G.-S., and Jeong, D.-H.: Influences of Environmental Factors on Water Runoff and Hillslope Erosion in Timber Harvested Area, J. Korean Forest. Soc., 84, 226-238, 1995.

Yoon, K. S., Kim, C. W., and Woo, H.: Application of RUSLE for Erosion Estimation of Construction Sites in Coastal Catchments, J. Coast. Res., 1696-1700, 2009.
Zapata, F.: The use of environmental radionuclides as tracers in soil erosion and sedimentation investigations: recent advances and future developments, Soil Till. Res., 69, 3-13, 2003.

Zhang, X. B., Li, S. L., Wang, C. H., Tan, W. P., Zhao, Q. C., Zhang, Y. Y., Yan, M. Q., Liu, Y. L., Jiang, J. J., Xiao, J., and Zhou, J.: A study of sedimaent delivery from a small catchment in the Loess Plateau by the Cs-137 method, Chin. Sci. Bull., 35, 37-42, 1990. 